\title{
Gem-Associated Protein 2
}

National Cancer Institute

\section{Source}

National Cancer Institute. Gem-Associated Protein 2. NCI Thesaurus. Code C114435.

Gem-associated protein 2 (280 aa, $\sim 32 \mathrm{kDa}$ ) is encoded by the human GEMIN2 gene.

This protein is involved in the assembly of small nuclear ribonucleoproteins that build the spliceosome. 